\title{
Philosophy of Education in North America: Where has it been? Where is it going?
}

\author{
James Scott Johnston
}

Queen's University

\begin{abstract}
This paper examines the question of philosophy of education's direction through an examination of its historical self-understandings. The North American, and particularly, U.S. context is highlighted. The thesis is that philosophy of education must reconstruct itself through attention to its past self-understandings, but most importantly, through acceptance of projects, issues, and topics that are relevant to it, and not simply to philosophy or educational practice. Some consequences of this thesis are presented at the end of the paper.
\end{abstract}

Key words: philosophy of education; Dewey's influence; educational theories; historical self-understanding; pragmatism

RESUMEN

Este artículo examina el problema de la dirección de la Filosofía de la Educación, por medio del examen de sus auto-comprensiones históricas. Se destaca el contexto norteamericano, y especialmente el de los Estados Unidos. La tesis es que la Filosofía de la Educación debe reconstruirse a través de la atención a sus auto-comprensiones en el pasado, pero, aún más importante, a través de la aceptación de proyectos, cuestiones y temas que son relevantes para ella, y no meramente para la filosofía o la práctica educativa. El artículo finaliza con algunas conclusiones que se derivan de esta tesis.

Descriptores: Filosofía de la Educación, influencia de Dewey, teorías educativas, auto-comprensión histórica, pragmatismo.

RÉSUMÉ

Ce papier examine la question de la direction prise par la philosophie de l'éducation à travers un examen de ses compréhensions historiques d'elle-même. Le contexte nord-américain, en particulier celui des États-Unis, y est souligné. La thèse est que la philosophie de l'éducation doit se reconstituer par l'attention qu'elle portera aux diverses manières de se comprendre dans le passé, mais ce qui est plus important, par l'acceptation de projets, de questions et de sujets se rapportant à elle-même, et non simplement à la philosophie ou à la pratique éducative. Certaines conséquences de cette thèse sont présentées à la fin du papier.

Mots-clés: La philosophie de l'éducation; I'influence de Dewey; les théories éducatives; une compréhension historique de soi; le pragmatisme 


\section{Educational Needs; Educational Theories}

Taturalism is "the greatest heresy in educational doctrine," (Cremin 1962, 1 p. 17), writes William T. Harris, the first National Commissioner of education and avowed anti-naturalist. Critical of Rousseauist impulses and ever fearful of the disintegration of the social order, Harris manifests a profound tension not soon found again in educational theory: a tension between the needs, rights, and destiny of the individual and the progress of private and public social institutions (Cremin 1962, p. 18). I single out Harris because he is emblematic of educational theorists of his generation: those that bring a certain way of thinking to educational aims and purposes not repeated by future generations of philosophers of education. Harris' idealism is no doubt behind the attempt to maintain the two contradictory tendencies of individualism and social progress. Educational theory would soon dissolve the tensions by dissolving the contradictions. New contradictions would of course emerge, but no attempt to weave them into a systematic garment would again occur.

Harris is emblematic of another tendency: the tendency to infuse educational theory with a particular philosophical approach. In Harris' case, this is Absolute Idealism. Unlike Mann before him, or Jefferson for that matter, Harris self-consciously follows a singular philosophic system and education is part of this system. Harris' example is but the first: it is progressivism and in particular, the almost wholesale allegiance to the philosophy of John Dewey, beginning in the period prior to the First World War and extending up through to the Cold War, that the largest infusion of philosophy into educational theory yet seen. It will do to cover briefly the relationship of Dewey's philosophy to progressivist education-not so much to review the material as to set the stage for the scene that follows.

Dewey famously grounds his work in the concerns of democracy, of solutions to social problems, and of problem-solving inquiry (Dewey 1980; Dewey 1991). As well, his work famously eschews abstract and metaphysical discussions of the ultimate aims, nature of, and purposes for, education, beyond the claim that education is growth (Dewey 1980). Progressivism, the name given to the broad social reform movements extant at the end of the 19th and beginning of the 20th centuries, ties in with Dewey's concerns as it is concerned with the social status of the poor, the working classes, immigrants, women, African-Americans, and others ruthlessly exploited by industry and laissez-faire economics and government policies (Cremin 1962). Progressivism thinks the common schools capable instruments of solving social problems and Dewey's educational work provides the philosophic impetus to begin doing so.

Of course, none of this is news to anyone remotely knowledgeable of the history of North American education. My point here is otherwise: because of the wedding of progressivist social planning and Dewey's philosophical and educational theories, little else in the way of educational theory is historically developed and what has developed takes on a broadly progressivist outlook. Until Marxist-inspired work begins in earnest in the 1960's and 70's, educational theory is dominated by progressivism and particularly, Dewey's. Dewey's legacy affects an almost complete silence from other philosophic voices. I will discuss this further on. For better or for worse, Dewey continues to exercise a deep and abiding influence on the philosophy of education. ${ }^{1}$ 
There is of course, another progressivism. This progressivism, often labeled 'scientific', is the evil twin of its Deweyan counterpart. This is the progressivism of the social efficiency movement - the movement to construct the schools along the lines of the 'best' factories of the day. Inspired by the Taylorism of the assembly plants, and utilizing the best psychological knowledge of the time, this movement is largely responsible for the testing and tracking movement that takes hold after the Second World War. This movement, rather than Deweyan progressivism, becomes the norm in public schools. However, this is beside the point: for scientific progressivism at its core, is bereft of theory. There is little, beyond Spencerian positivism, some spurious psychological insights into the nature of human behavior, coupled with various beliefs about the social status of the deserving that drive this movement. There is no educational philosophy here to rival that of Dewey's.

This is precisely what is at issue: there is nothing else under the sun. The lack of alternative educational philosophies (with recent exceptions, as I shall mention) coupled with the dominance of Deweyan progressivist theory means that virtually any theoretical work done in, on, or about, education is (broadly) progressivist. Most educational theorists consider this a blessing: but the lack of suitable alternatives for educational theory and philosophy in the first half of the twentieth century has led to an educational theory in the second half that is for the most part intellectually derivative. Though many seemingly novel theoretical advances have taken place in the latter half of the twentieth century, few of these count as original. Beyond analytic and linguistic work in Britain (Kaminsky 1993), and neo-Marxist and Critical-theoretical work on both continents (both beginning in the 1960's), there is little original scholarship. ${ }^{2}$ Indeed, the case of the neo-Marxist and Critical-theorists is ambiguous on this point as well. I say this because of the frequency of comparison of the work of neo-Marxist and Critical-theorists to the Progressivist work of the early part of the twentieth century. Simply put, the twin goals of social reform and a commitment to educational practise are manifest in the self-understandings of most philosophy (and philosophers) of education.

However, I am getting ahead of myself. I want to go back and look at the progressivist contributions to educational theory before I discuss the reaction to these. For as I will maintain, progressivism, though heavily criticized by perrenialists, certain neoMarxists, anti-liberals, anti-capitalists, and some students of cultural studies, nevertheless is not only able to weather the storm, but in many ways is found in the very aims and purposes of those who criticize it. ${ }^{4}$ I claim that Pragmatism (at least in North America) is the sole viable philosophic framework of education.

Concomitant with the rise of educational theory in the progressive era is the rise of education as a legitimate discipline. The progressivist era is the heady time of science, of the birth and development of the research university, of new disciplines, of the fragmentation of established fields. Schools of education and teachers colleges displace the normal schools and do so with a bona fide educational theory in tow (Cremin 1988, p. 242). Increasingly, universities begin to add graduate education programs to their ranks. These emphasize research as well as teaching. State Universities, particularly those founded under the Morill Act of 1862, are poised to participate in this venture (Cremin, 1988, p. 242-244). With few exceptions, the leading theoretic program in these universities is that of progressivism (Larabee 2004, p. 142-143). 
There are of course, challenges to progressivism, some in the name of science. Ellwood Cubberley's experiment at Stanford, to train administrators in the techniques of Fordism, is an example of this (Welker 1992). Stringfellow Barr and Scott Buchanan's attempts to bring a classical curriculum to St. John's College in Maryland in the 1930's, as well as the now-famous Great Books seminars led by Robert Hutchins and Mortimer Adler at the University of Chicago, are examples of a humanist tendency that begins to take hold. Nevertheless, these are examples that (Cubberley aside) fall outside of the schools of education. Indeed, these programs are often hostile to the programs in the schools of education at the time.

The case of Cubberley is interesting because it highlights that most interesting phenomenon of early twentieth century education: the tendency for those of opposite ideological poles to rely on similar means to obtain what is for them, the best in educational practice. Here, I am referring to science. Both Deweyan progressives and the scientific progressives of Cubberley's ilk turn to science to validate best practices and yet with vastly different agendas. While the Deweyan progressives trumpet social reform, and improvement, dialogue, experience, and communication, the scientific progressives trumpet testing, sorting, merit, efficiency, and nation building. Not surprisingly, much Deweyan progressivism takes place in departments of teacher education, and much scientific progressivism in departments of psychology. Indeed, as one historian has claimed, Deweyan progressivism had lost the race coming out of the gate: by 1915 , it was clear that new scientific management techniques would capture the day in American schools (Lagemann 1989). Despite what teachers' colleges were doing with progressivist theory, the fact the administrations of colleges and schools across the nation were adopting the scientific methods on the recommendations of psychologists such as Thorndike, meant little gain was actually made.

By the late 1930's, wholesale changes to the American public school curriculum take place. Thousands of schools adopt a variant of Progressivist William Kilpatrick's 'project' method, or one or another variant of the 'activity' method. Social reconstructionists such as Harold Rugg and George Counts, while pressing for the schools to engage in social changes, invest their time and energy in re-vamping curricular materials (Cremin 1988). Rugg's American history textbooks arouse much antagonism during the Cold War period of the late 1940's and early 1950's - the beginning of the anti-progressivist backlash (Tanner 1991). In terms of practical curricular reform, the Deweyan progressives obtain mixed results. However, in terms of theoretic reform, Deweyan progressivism is the only contender and emerges victorious almost by forfeit (Larabee 2004). The scientific progressivism, rooted in the behaviorism of Edward Thorndike and Lewis Terman, and weaned on the new testing movement, is in no position to offer anything like a systematic view of human nature; its metaphysics, ethics, social and political thought, and theory of knowledge are either absent or primitive. However, pragmatism, the vaunted philosophy that undergirds progressivism, provides what scientific progressivism lacks.

The appeal to specific models, aims, and purposes is equally the appeal to specific techniques of inquiry. This of course, is the instrumentalism and later, experimentalism brought to the theoretic forefront by Dewey. Dewey's experimentalism offers not only a 
way to pursue substantive inquiry into ethics, morals, knowledge claims, metaphysics, and politics, but does so with education front and center. It is through education that one learns the habits necessary to live and prosper in twentieth century North American democracy, as well as the tools, in the guise of scientific method, to transform society to meet pressing and future needs. Nothing that the behaviorists can offer remotely comes close to such a package. The behaviorist model suggests passivity in place of activity, a Lockean 'blank slate' on which knowledge inscribes. The role of the school is merely to provide the inscriptions. Dewey's model offers so much more for education to do: teachers and institutions have the enviable task of preparing children for citizenship through facilitating the development of the habits of inquiry, conduct, and communication - the 'associated living' that Dewey famously describes in Democracy and Education (Dewey 1980, p. 93).

Dewey writes self-consciously for teachers. Three of his most famous works, School and Society, How We Think, and Democracy and Education, have this audience in mind. All of these, at one time or another, become textbooks and it is not surprising that hundreds of thousands of teachers over the last century have had exposure to these. Nor should it be surprising that these works continue to have influence in schools of education today. Nothing that the scientific progressives write matches the popularity or depth of Dewey's works on education. Although scientific progressivism is the 'winner' in the race to control public education, at least in the United States, Deweyan progressivism is the clear winner in schools of teacher education (Larabee 2004, p. 143).

The Second World War brings on many changes in American Education, most notably the restructuring of the high school in accord with the Comprehensive model of James Bryant Conant. Tracking, testing, and grouping begin in earnest: high school students entering college begin to receive the S.A.T. In addition, the Cold War initiatives - providing the nation with more scientists, engineers, technicians, and those who would support them - lead to yet another restructuring of the high schools and to a lesser degree, higher education. The progressivists lose whatever authority they once had, and subsequently, democratic initiatives in the schools falls apart (Tyack 1974; Kleibard 1985). Again, the trumpets that are sounding do so to the tune of scientific progressivism. However, there is not so much a theory of education behind the restructuring as a political agenda, to win the Cold War through the containment of the Soviet.

In the late 1960's and early 1970's, a seeming changing of the guard begins to take place in schools of education. Neo-Marxism, a seemingly non-progressivist theory, comes to the forefront. Here, I use the terms, 'neo-Marxism' and 'neo-Marxist,' to refer to Marxism and Marxists, and Critical Theory and theorists (though these differing schools often resist the label 'neo-Marxist,' nevertheless, for the purposes that I have, they all agree on the point in contention). The Vietnam War has much to do with the general disillusionment in then current American and Western politics. As well, larger proportions of historically disenfranchised peoples - African Americans, Latino/as, and the impoverished - buoyed by the Civil Rights movement and President Lyndon Johnson's 'Great Society' initiatives rally for recognition. Often, these groups turn to Marxist-inspired rhetoric to make their claims. Neo-Marxism eventually becomes a 
respectable subject in the Academy: the McCarthyism of the 1950's gives way and continental thought, with its closer relationship to neo-Marxism, begins to be in vogue. Nevertheless, outside the Academy and particularly in broad swathes of Middle America, neo-Marxism gains no ground.

Many schools of education respond by legitimizing the study of Marx, feminism, revolutionary pedagogy, liberation pedagogy, and other theories. It seems that the earlier progressivist literatures are being set aside in favor of the newer, more radical works of neo-Marxism and critical theory. There certainly are a few neo-Marxist criticisms of progressivism, beginning in the 1960's. Largely, though, criticisms of progressivism come from outside the Marxist tradition, from those, while not espousing any particular ideology, and are clearly not enamored with liberalism. These see the progressive era as a time of rampant social engineering. Run by experts with scientific training, society is merely reproducing the capitalism of the middle-classes. Dewey is himself implicated in all of this: it is pragmatism as a philosophic theory making the bourgeois economy palatable to the masses and suggesting a scientific means of ensuring its reign. The socalled 'Illinois Revisionists' (Clarence Karier, Paul Violas, David Hogan, and Joel Spring), are examples of these thinkers.

These voices do not exist in the academic mainstream, though. Far more likely is the attempt to wed earlier Deweyan progressivism to fashionable neo-Marxist and criticaltheoretic rhetoric (e.g. Apple \& Beane 1995; Brosio 1994; Giroux 1983; McClaren 1994). There are many interesting similarities: both champion democracy and equal rights; both champion industry and labor; each has a 'theory' of alienation; as well, each concentrates on social reform and improvement rather than reproduction of the status-quo. Neo-Marxism's skepticism of present schools notwithstanding, each admits the school has an important role to play in social production. Beyond this, whereas neo-Marxism and critical theory generally have little to say about metaphysics, the theory of knowledge, or ethics, pragmatism - the philosophic counterpart to progressivism - does. Pragmatism is fuller and richer than Marxist-inspired philosophy, because (early) Marxist-inspired remains rooted in the dogma of materialism and historicism. Though critical theory has done much to remove the overt dogma from NeoMarxism, the lack of a systematic or organic understanding of human nature limits its helpfulness to the aims and purposes of education. I say this fully aware that critical theorists attempt to reconstruct from subject-centered reason models of dialogue, procedures, and norms of democratic societies. This is precisely the point, however: there is little outside of socio-political understandings in these attempts, and consequently little developed theory regarding topics such as logic and metaphysics, is proffered. This is particularly the case with those that do critical theory in education: While they are keen to redress social and political inequities, including class, race, gender, ableist, and others, they do not attempt to reconstruct our understandings of what it means to be human. 


\section{Educational Theories; Philosophic Models}

I turn now to philosophy of education and particularly, its role in lending support to one or another of the various theories of education. I begin by discussing the formation of philosophy of education societies in America, as well as debates regarding the nature of philosophy of education in philosophical journals carrying articles on education. Philosophy of education is a new discipline with a history spanning slightly more than 70 years, though the rudiments of the discipline stretch back to ancient Athens and beyond (Kaminsky 1993, xiii). In the 1930's, several organizations geared towards social reform of the schools are founded. Notable among these are the Progressive Education Society (PES) and the John Dewey Society (JDS). In addition, the journal, The Social Frontier (SF), is established. All of these organizations served to bring the goals of social reform and social reconstruction of the schools to a general audience. Members of the PES find themselves on the boards of SF and the JDS. John Dewey, George S. Counts, William Kilpatrick, Ralph Tyler, John Childs - all eminent philosophers and educational theorists - are among the various members of these organizations over the span of the first twenty years. In 1935 for example, the JDS establishes itself with William Kilpatrick as President of the Board and John Dewey and Charles Beard as the first outside fellows (Tanner 1991).

Early debates in these vehicles concerned the point and purpose of social reform. It was not that the members of these organizations were inimical to social reform: far from it. Rather, the debates concern the role of the schools in any ostensible social reconstruction. George S. Counts publishes the controversial Dare the Schools Build a New Social Order. Dewey responds to Counts in an address before the National Education Association, entitled, "Education for a Changing Social Order" (Dewey 1989), and mitigated Counts' rhetoric. Dewey, together with Sydney Hook and Ralph Tyler, are wary of Counts' invocation of the schools in radical social overhaul (Tanner 1991). Though the SF, the PEA, and the JDS seem pulled in different ideological directions, the case in fact is that social reform is not in dispute: only the difficulty of its establishment is in contention. The goals of progressivism are firmly ensconced in each of these organizations, as they are in each of the teachers colleges represented by the members of these societies.

By the end of the Second World War, though, an ideological sea change occurs in legislative and political circles in America and progressive organizations find themselves on the defensive end of debates concerning the aims and purposes of education. The PEA closes down, and what membership remains, transfers to the JDS. A ban of Rugg's textbooks across the nation was underway by the early 1940's: but this was just the beginning of a further crackdown on the seemingly leftist ideology of the progressivists. In 1951, Rugg gives a lecture at Ohio State University, lamenting the attack and subsequent removal of his textbooks from schools. This hastens the Board of Trustees of the College of Education at Ohio State University to condemn Rugg's presence at the university (Tanner 1991). The JDS spends a good part of the subsequent decade after this fending off right-wing McCarthyist attacks on the freedom of speech and the criticism of university teachings. 
The PEA and the JDS are not the only organizations devoted to the philosophy of education. At least two other organizations devote themselves to philosophic issues and concerns: the Philosophy of Education Society (PES) and the National Society for the Study of Education (Tanner, 1991). The National Society for the Study of Education (NSSE) is the successor to the earlier, National Herbart Society (of which Dewey was an early, active member). The function of the NSSE is to bring together a number of respected scholars on topics and themes in education and make the results available to a general audience of educators. The PES is comprised of members whose interests often lay outside of educational theory and schools, but it turns out a manifesto on the state, role, and scope, of philosophy of education. In 1970, The Committee of the Philosophy of Education Society brings out a document entitled "The Distinctive Nature of the Discipline of the Philosophy of Education." It will do to look at the tenets in this document. I will look at the Yearbooks produced by the National Society for the Study of Education first and follow with an examination of the document produced by the Philosophy of Education Society

The NSSE publishes three Yearbooks on the topic of philosophy of education. The Forty-first Yearbook (Nelson 1942) is devoted to philosophy of education, as is the Fifty-fourth (Nelson 1954) and Eightieth (Soltis 1981). Replete with essays by such notables as William Kilpatrick, Harry Broudy, Mortimer Adler, and John Childs, the first two Yearbooks concentrate on a historical presentation of educational ideas, with a particular focus on extant progressivist, neo-Thomist, Realist, Idealist, and analytic thinking. They pay little attention to philosophic examinations of issues or problems. Educational issues are less of a concern for these writers: what is important is the placement of education in the context of philosophic schools of thought. As a result, these yearbooks resemble primers in their scope and function. However, something new, something that does pay attention to these, is on the horizon.

In 1981, the third of three Yearbooks, the Eightieth Yearbook, is issued. By this time, analytic philosophy has emerged as the dominant school of thought in philosophy of education, and the yearbook demonstrates this nicely. Gone is the attempt to summarize the main currents in the sub-discipline; instead, the yearbook focuses on "potential relationships between philosophy and education," with a secondary role for history (Soltis 1981, p. 3). Soltis argues that this is necessitated by "a serious professional mismatch between expectation and delivery" (Soltis 1981, p. 2). Soltis expands on this comment,

Quite frequently, it seemed to us, the philosophical expectations of educators were not being met by what was being delivered by professional philosophers of education...Learned labels like idealism, realism, pragmatism, or perennialism, progressivism, essentialism were becoming less and less helpful for understanding what many philosophers of education were doing. Even the newly added labels of "phenomenology" and "linguistic analysis" seemed to name odd methodologies and philosophical research programs rather than world views and systematic educational ideals. Thus, for many people the very meaning of having a philosophy of education as the holding of a world view that supports a systematic set of 
beliefs about educating was being violated or at least seemed to be disregarded by philosophers who were busy analyzing concepts, bracketing the world to obtain pure phenomenological descriptions, or just plain philosophizing about some narrow and particular topical educational idea or issue (Soltis 1981, p. 2-3).

Soltis notes that increasing specialization is the culprit, here, and suggests to the readers that "...viewing philosophy of education from this single perspective [of world views] is too narrow and cuts educators off from a richer perception of the wider field of philosophical endeavour that has developed in recent years" (Soltis 1981, p. 5). In other words, Soltis recommends that we pay less attention to schools of thought (worldviews) and more attention to issues and concerns arising out of education writ large.

Harry Broudy's piece, "Between the Yearbooks," accomplishes the 'historical task' of tying the three yearbooks together. Broudy speaks of philosophy of education as "Januslike" and concerned with "problems of philosophy on the one hand, and with problems of schooling on the other (Broudy 1981, p. 15). This state of affairs is what leads to the 25-year gap between Yearbooks. "Presumably" Broudy says, "the primary audience and the focal problems of philosophy of education are educational, but the inevitable tensions between obligations to practitioners and to the field as a domain for academic inquiry werer heightened as the study of philosophy of education in the 1950s and 1960s became more philosophically technical and increasingly a field for specialization in doctoral study" (Broudy 1981, p. 28). Broudy claims this is of a piece with the larger phenomenon of topic-focused research, as opposed to' isms.' In addition, historical events such as the Vietnam War, the Civil Rights Movement, and the "life-styles" changes that occurred then, contribute to this (Broudy 1981, p. 30).

Summarizing the changes in topics between the Yearbooks, Broudy follows with prescriptions for philosophers of education. The first (and to my mind, most important) is that "They have a right to expect that philosophers of education will address themselves to problems of education in general and how those problems impinge on schooling" (Broudy 1981, p. 33). Problems of education in general are eo ipso social problems, and what Broudy proclaims is that philosophy of education should be in the business of examining social problems, hopefully with an eye to their amelioration. As well, educators have "a right to expect from philosophers of education a clarification and elucidation of concepts and arguments used in educational literature, especially the literature of educational controversy" (Broudy 1981, p. 34). Broudy recognizes the centrality of the then-popular analytic approach to philosophy of education. Finally, "School people [sic] have a right to expect from the philosopher of education a careful examination of proposals and policies with respect to their consequences and possibilities, in the round, so to speak" (Broudy 1981, p. 34). This ties nicely into Broudy's first prescriptive: that philosophy of education should work towards social reform, here through policy analysis.

The topics covered in the Eightieth Yearbook are as follows: Curriculum Theory, Theory of Teaching, Epistemology, Aesthetics, Logic, Ethics, Social Philosophy, Philosophy of Science, and Metaphysics. Gone is the 'schools of thought' approach; in its place are the traditional divisions of philosophy, together with attention to curricula 
and pedagogy. The articles themselves are varied as to the question of what role for philosophy of education. Jane Roland Martin's article, for example, castigates the "ivory tower" approach of recent epistemological work in philosophy of education, and recommends more attention to social relationships and social theory (Martin 1981, p. 55-56). Donna Kerr's article points out the need for a theory of teaching separate from a theory of learning, as well as the need to distinguish between the 'phenomena' of teaching and the 'theory' of teaching. The article voices the need to examine what we mean by 'excellence' in teaching and does so from a broadly analytic perspective (Kerr 1981, p. 91-92).

Three notable themes stand out in the third Yearbook: the first is the move away from schools of thought ('isms') to the traditional divisions (ethics, logic, metaphysics, and theory of knowledge) within philosophy. The second is the self-understanding of the sub-discipline as in the service of educational reform, meaning social reform. The third is the turn towards analysis of concepts and meanings. While the third theme was already beginning to wane, and the first theme never fully catches on, the second theme, that of philosophy of education in the service of educational reform, remains strong, as I shall further show.

The PES document begins by addressing what is no doubt obvious to everyone concerned: philosophy of education, whatever it is, is amorphous. Characteristically enough, the Committee issues a caveat: "What philosophy of education ought to be and do is a highly debatable matter insofar as differing answers come from differing philosophical positions. This statement, therefore, attempts only to delineate the basic, common, or minimal characteristics of the discipline within which we find these differing answers and positions (Champlin in Lucas, 1970, p. 111). I note three characteristics ascribable to the philosophy of education as laid out in the document:

(1) Unique theoretical tools consisting of hypotheses, concepts, and categories (such as meaning, truth, value, method). (2) The employment of these tools in the examination of the criteria, assumptions, and/or reasons, which guide assessments, judgments, and choices. (3) A scholarly acquaintance with events, practices, circumstances, and/or ideas relevant to that which the philosophy is of (that is, education, art, politics, science, or religion) (Champlin in Lucas, 1970, p. 111).

The framework that addresses these questions and concerns is notably analytic.

Here, a broad construal of education is evident. "The term education may refer to any deliberate effort to nurture, modify, change, and/or develop human conduct or behavior; or it may refer to organized schooling. For purposes of consensus we adopt the latter [institutionalized schooling] (Champlin in Lucas 1970, p.112). Why consensus is such a powerful impetus, they do not say. The document continues: "Wherever education, thus defined, is taking place, we find: (1) Preferences for certain procedures, resources, and goals (methods, means and ends) implicit or explicit in the undertaking. (2) The employment of criteria, guides, or reasons with which procedures, resources and goals are determined and established (Champlin in Lucas 1970, p. 
111). Here, we have a methodical and quasi-scientific approach to the philosophic problems extant in education. The Committee brings this methodology to bear on problems of philosophy of education in three distinctive yet interrelated 'phases.' These are the 'descriptive-analytical,' the 'critical-evaluative,' and the 'speculative.' The descriptive-analytical deals with the criteria by which choices within education are made; the critical-evaluative, with developing new criteria for alternative thinking in the philosophy of education, and the speculative with the construction of the new alternatives themselves (Champlin in Lucas 1970, p. 111).

Finally, the committee puts forth a statement regarding the institution of philosophy of education. "In those institutions having courses in the philosophy of education, we should have provision for the study of, and the gaining of skills in, the conceptual materials (content) peculiar to the discipline. The teaching personnel should be equipped with, and trained in, the conceptual tools and skills peculiar to the discipline (Champlin, in Lucas 1970 p. 111). Philosophy of education takes on a manifestly conceptual function; by analysis of concepts and meanings, using a quasi-scientific approach, philosophy of education articulates alternative conceptual frameworks while demolishing others. Although no mention of Dewey occurs in the text, his scientific approach to the solution of educational problems is notable in the rhetoric of method. Likewise, this attention to concepts and conceptual development foreshadows the coming acceptance of analysis and analytic philosophy as the pre-eminent standpoint: one that would dominate philosophy of education in the 1970's.

The 1950's sees the birth of a new journal: Educational Theory. The first issue, May 1, 1951, inaugurates a new approach (Feinberg and Odeshoo 2000, p. 289-292). Archibald Anderson of the University of Illinois is the first Editor-in-Chief. The SF had closed down. The PEA's journal, Progressive Education - the final remnant of that organization - is at this time in decline and closes down by the end of the decade. Educational Theory becomes the primary vehicle for philosophy of education in North America, and to this day continues to be. William Kilpatrick has the lead article in that first issue. The title was "Crucial Issues in Current Educational Theory." According to Feinberg and Odeshoo, Kilpatrick uses the article largely as a stump from which to exhort his own agenda. Suffused with the rhetoric of consequence, Kilpatrick argued for the furthering of the progressivist agenda. Archibald Anderson, the editor in chief, takes a more conciliatory tone in his inaugural editorial. He claims that the journal is to foster the continuing development of educational theory and that the journal is to be open to disciplines outside that of education if the research is of interest or use to educators (Feinberg and Odeshoo 2000, p. 290).

The first decade apparently produces a wide array of articles. Feinberg and Odeshoo, speaking of this array, note that, “...the range of article types that can be found in the journal is in many ways wide enough to resist any easy classificatory scheme or strict thematization" (Feinberg and Odeshoo 2000, p. 296). Nevertheless, there are some regnant themes. 'Isms' apparently were in vogue: many of the articles dealt with one or another of the reigning philosophic approaches to education. Others apparently deal with particular philosopher's perspectives on education. Curiously, articles on John Dewey are rare. Notable as important are articles that define educational 
theory in relation to philosophy. "A great many of these discussions attempted to clarify the nature of the relation of between philosophy and education; and their point was to show that the philosophy of education constituted an autonomous field of study that could not simply be reduced either to education or to philosophy" (Feinberg and Odeshoo 2000, p. 297). Such a bold statement is misleading: Indeed, though philosophic methods are abundant, the topics and consequences belonged in the main to education, and not philosophy proper, nor to some other discipline. Interestingly, Feinberg and Odeshoo claim that it has been only recently that Educational Theory has allied itself closely with the discipline of philosophy of education; early essays often draw on sociology, psychology, literature, and economics, in developing novel educational theory (Feinberg and Odeshoo 2000, 297).

Feinberg and Odeshoo conclude that theory, as represented in the 1950's in Educational Theory, is entirely too wedded to the prevailing desire towards social engineering.

However, the consensus conception of theory was intact at the end of the decade. Although Anderson and Kilpatrick differed about the representation of the theory in the journal, they shared a widely accepted understanding of the role of theory in education. Theory was that which grounded social change, and was conceived as the analogue of engineering...Both...are restricted views of theory, and each fails to understand that human history differs from scientific theory and that physics is not always the best model to use when understanding educational affairs (Feinberg and Odeshoo 2000, p. 205).

Although many, if not most of the articles in Educational Theory deal with the intersection between philosophy and education, and many further with educational issues of the time, nevertheless, the presence of social reform through education is the norm for the vast majority of these.

Maxine Greene discusses Educational Theory in the 1960's. Though differing conceptions of educational theory comes to the fore in the 1960's, the same general task of providing philosophically informed educational practice, remains.

The inevitable question for educational philosophers had to do with the connection between philosophy and educational practice. What did the philosopher have to say about the "new" math, or the social studies curriculum that raised so much ire in Congress? What of distinctions among methodologies or different "learning styles?" Did the nature of a philosophic system or point of view affect the conception of education or educational practice under consideration? How did a particular epistemology govern approaches to subject matter? (Greene 2000, p. 309).

Curiously, though, Greene claims,

It should be pointed out as well that the "movements" approach, with its reliance on generalizations taken from the great systems of thought, rendered philosophic 
inquiry impersonal and distanced...Even in those cases [of exceptions] however, I find little attention paid to the concreteness of events in the classroom or to the commonsense language best equipped to handle them. Similarly, there was little effort exerted to the capture the voices and...the "actions" of teachers actually involved in the process of teaching (Greene 2000, p. 310).

Though the discipline does confront novel philosophic approaches to human nature (such as existentialism and phenomenology) and makes the connection between these and education, yet in Greene's estimation, philosophy of education is already in decline, apparently so for not emphasizing the social aspects of education enough (Greene $2000,314)$. Greene tells us that there were a few "purely" philosophical discussions..."(Greene 2000, p. 315). This suggests, on the part of Greene, though, that the vast remainder are of practical importance. In addition, there seems to be a fear, manifest in the articles that in sacrificing clarity and scholarly detachment, the newfound discipline becomes an ideology. Greene agrees that this is indeed the case, and chides the discipline for overemphasizing these fears at the expense of, “... recognition of the kind of multiplicity that was beginning to confront teachers, for all the slow entry of African-American children onto the broader educational scene" (Greene 2000, p. 317).

The 1970's witnesses the wholesale acceptance of analysis as a legitimate topic for philosophy of education. The 1970's are also the decade that sees the emergence of hitherto unheard voices: feminist, minority, and multiculturalist - though this emergence takes place towards the end of the decade. Equally though, the Deweyan concern that educational theory abrogates its social responsibilities, is increasingly heard (Phillips 2000, p. 323). Indeed, the author of this article, Dennis Phillips, seems to hold to this last point. Invoking Dewey's The Quest for Certainty, Phillips comments on an essay by A. Berry Crawford and Warren R. Brown, entitled, "Missing: A Viable Aim for American Education." He says, "Philosophers of education who wish to live up to the spirit of the desideratum quoted at the outset of this section cannot afford to ignore the difficult details of application, a moral that I daresay we have not sufficiently internalized thirty years after the appearance of this particular essay. And, just as crucially, we need to warrant our claims that the solutions we offer really are solutions, and are not merely the equivalent of snake oil" (Phillips 2000, p. 324).

Along with philosophically interesting discussions of single philosophers, Phillips notes that there are several 'themes' discernable from the articles of the 1970's. Two of these deserve mention here. The first is the reminder that philosophy of education must first do good philosophy - a point with which Phillips seems wholeheartedly to agree. The second is that what counts as philosophy of education has undergone a drastic change. Phillips puts his point this way: "But not only is there general silence about the 1970's [today], and a change in the topics of professional conversation, the way in which the conversation is carried out has undergone dramatic transformation in general the style of writing is one that is quite unfamiliar to one who reads with the eyes, and tastes, of a "seventies-year-old." For example, there are few (some perhaps, but very few) essays in recent years that remind one philosophically and stylistically of the essays...by Robert Ennis. How does one interpret these changes? Were the 1970's 
irrelevant? Has philosophy of education really undergone dramatic transformation?" (Phillips 2000, p. 337). Phillips attempts to sketch answers to his own questions. He draws from Thomas Kuhn's talk of 'paradigm shifts' as a means of understanding this phenomenon: there are gains and losses in any discipline and it so happens that philosophy of education since the 1970's largely incurs losses and these in the areas of rigor and consistency of argumentation.

The 1980's seems to begin with considered 'traditional' topics: Harry Broudy arguing for more metaphysics in philosophy of education and Jonas Soltis arguing for more linguistic analysis (Kholi 2000, p. 342). However, this trend is fast fading. Analysis would take its last gasp in this decade, and questions of the relevance of philosophy-tophilosophy of education become less and less prominent. Harvey Siegel's pronouncement that, "As philosophers of education, our primary purpose musts be develop and deepen our understanding of the whole host of philosophical issues raised by the practice of education" (Siegel 1981, p. 46), gives way to self-criticism in the form of gender, class, and cultural studies. Jane Roland Martin's essay of 1981, entitled, "The Ideal of the Educated Person," is an essay symptomatic of this new trend. According to the author of this article, Wendy Kholi, Martin "...takes on the established canon of philosophers of education, especially the work of R. S. Peters, to underscore the way we all have been initiated into male cognitive perspectives when discussing the ideal of the educated "man" (Kholi 2000, p. 349).

Critical Theory makes its 'big break' at this time. Henry Giroux's articles feature in a debate in a 1984 issue of the journal, and represent perhaps the first example of largescale attention to prevailing social theory (Kholi 2000, p. 349). Other novel representatives of emerging social and cultural criticism include Susan Laird, Jo Anne Pagano, and Nicholas Burbules. The latter develops "A Theory of Power in Education." The goal is to synthesize "“"creatively and constructively a range of perspectives on the takenfor-granted concept of "power"” (Kholi 2000, p. 349). If indeed power was once takenfor-granted, it certainly is no longer. Kholi credits Ralph Page with having the openness and the foresight to see the value of these articles and to publish them. She notes that he is "...committed to enlarging the readership and more accurately reflecting the range of ideological perspectives in the field....” (Kholi 2000, p. 349).

Kholi proudly proclaims that the journal keeps a balance of perspectives during the 1980 's and that, "Boundaries [in the philosophy of education] were drawn and redrawn, determining who counted as a philosopher and who did not - over what counted as philosophy and what did not.... The academic consensus about what counted as "good" philosophy was challenged" (Kholi 2000, p. 355). What seems not to have been challenged, though, is the continuing relevance of philosophy of education for schooling: the question of whether or not philosophy of education has anything useful to give to education, as Harvey Seigel raised early in the decade, seems to require no further answer. What seems not to be in question, then, is the appropriateness of the model-a progressive model-that counts the work of philosophy of education bearing in the first place, allegiance to, the larger aims of the schools and social reform.

Megan Boler opens her essay on the 1990's by saying that, "This is a tale about the "postmodern" subject who has, tragically, come of age in a climate of crisis. To grow up 
in the 1990's is, for many, to learn to live and breathe disasters of both global and local proportion" (Boler 2000, p. 357). Boler does not broach this crisis. Nor does she broach what these global and local disasters are. Nonetheless, with invocations of the abandonment of God, the predominance of computer-mediated interaction, and discussion of juvenile crime and delinquency measures in California, one would be right to suspect that it has much to do with the perils of capitalism (both local and global) and the ongoing disenfranchisement of minorities. Boler is correct about this: in the 1990 's, "...debates about consensus and dissensus represent possibly the major intellectual debates...” (Boler 2000, p. 358).

Boler traces what she calls "interlocking themes of tragedy and pastiche as they intersect the role of listening in educational theory" (Boler 2000, p. 358). Rather than presenting a chronicle of events, themes of significance, or trends, she weaves together differing strands of educational theory into a novel garment. Here, the focus is on dissensus and difference. "Whether one is of the view that "difference" directs us toward revolutionary and fertile theoretical terrain and practice, or that it simply functions as a new hegemony, the 1990's as represented in the journal Educational Theory struggle with the politics of difference" (Boler 2000 p. 359). Politics becomes the focus of the journal. Nevertheless, as Boler rightly points out, Dewey scholarship continues unabated. As well, Boler claims that educational philosophy rather than history, sociology, cultural studies, or aesthetics constitutes the bulk of the articles. Boler does not consider that articles dealing with poststructuralist or postmodernist theories often count more as history, sociology, cultural studies, and aesthetics than philosophy, historically considered: for if she did, she would have to revise her estimate.

Nevertheless, Boler complains about the lack of "difference" in the journal. "I would say today, as an evaluative remark on the overall absences in Educational Theory, that what is missing are essays substantially addressing race, social class, popular culture, or cultural studies, with very little colonial or global studies, and relatively slight international representation in author or focus" (Boler 2000, p. 359). She does say that by 1993, though, "...one finds within the covers of Educational Theory increasing numbers of essays that are skeptical about the promise of discourses of plurality and equity, and hence skeptical about the value of consensus as an ideal goal" (Boler 2000, p. 373). Presumably, these essays count as essays in "difference:" essays that contribute to the discussions of topics that Boler bemoans as sadly lacking in the journal. Curiously, she concludes her essay by claiming that, "The moral lesson to be gained-if any-from this review essay is that one must live in the sense of disequilibrium" (Boler 2000, p. 380). That she is compelled to draw this conclusion upon looking at the sum of 10 years worth of educational theory is puzzling: doubtless, she finds something metaphysical in the pastiche and difference represented in the essays.

\section{Present Circumstances of Philosophy of Education}

The foregoing should be sufficient to show that, despite the varying trends in philosophy of education scholarship, (at least) two tendencies remain steady throughout; the 
first is the wholesale application of philosophy of education to issues of schools and schooling. The second is the general agreement of the project of John Dewey: education in pursuit of social reform and improvement. In North America at least, the role of philosophy of education to its parent disciplines is an uneasy one: particularly where philosophy is concerned. We need only witness the very recent debates concerning this in Educational Theory. I have much to say about these presently.

\section{The Critical Conversations}

First, I wish to discuss some preliminaries to this debate. These are notable prefatory remarks to what becomes a symposium on whether philosophers and philosophers of education are talking to each other. I turn to the edited volume, Critical Conversations in Philosophy of Education, by Wendy Kholi, and to the three essays on 'what counts as philosophy of education,' therein. Maxine Greene, Walter Feinberg, and D.C. Phillips write the essays on this topic. Greene's essay is the first and longest. Her central claim in responding to the question of 'what counts' is that,

...we cannot set aside the texts that compose so much of our tradition and provide so many of our references and allusions, texts by Jean-Jacques Rousseau, Immanuel Kant, Thomas Jefferson, John Stuart Mill, George Herbert Mead, William James, John Dewey, and Paulo Freire. Can we prevent such texts from being undermined by the "unforeseen" and the "unforeseeable?" How can we expose the inadequacies (and the racism, and the sexism) in so much of the discourse without disposing of the texts-and our own intertextuality-as well? Must they be shredded? Must we start again? (Greene in Kholi 1995, p. 6).

Greene then turns to passages of Virginia Woolf, Edward Said, and Helene Cixous and proclaims that our first-world identification of 'highest' with rationality and technicality is imperialist and hostile to imagination, feeling, and emotion. She says, "we do recognize, of course, that our slow acknowledgment of our long confinement to a "Eurocentric" canon has made some of us sensitive to the traces of colonialism in practice and in our thought" (Greene in Kholi 1995, p. 9). She quotes Michael Oakeshott approvingly in suggesting that education is a conversation. ${ }^{5}$ In this conversation, she speaks of the role of the educational philosopher:

Of particular interest to today's educational philosopher is the matter of plurality and pluralization. We can no longer speak in abstract terms about "Mankind" or "the child" or even "the partnership of this conversation." We are asked to think of persons in their plurality, in their distinctiveness, no one a duplicate of any other. At once, we are learning to acknowledge the worth and power of different cultures and civilizations, out of which identities are negotiated.... To learn to "recognize the voices" now is to pay heed where educators seldom paid heed before: to living beings of all classes, from almost countless countries on the globe. We are asked to recognize the sound of exile, of expulsion, of abandonment, we are being asked, as 
never before, to attend to the voices of all sorts of women, men, and children too, to empower them to make meanings in the disparate, sometimes savagely unequal lives they live (Greene in Kholi 1995, p. 13).

Greene's heady rhetoric of championing the disenfranchised leads her to claim that, "Whatever counts as Philosophy of Education today must begin in queer questions, those not susceptible to logical or empirical resolutions. Whatever shape they take, they must be defined with the contexts of multiple transactions, those in which diverse human beings are intimately involved" (Greene in Kholi 1995, p. 17). Greene has the expectation that philosophy of education, whatever else it does, will attend to the needs of the disenfranchised at some level and ideally, it will do this without restriction by historical dogmas such as the need for logical, empirical, or metaphysical confirmation. Whatever tools needed to solve the problem at hand ought to be the tools in use: if these tools are the tools of self-reflective criticism, then so much the better.

Walter Feinberg's essay is notable for its candor. Speaking of the point and purpose of philosophy of education, Feinberg proclaims, "To remind us that Philosophy of Education has something to do with schooling - a reminder that Greene, whose work in schools is legendary, does not need - is not to say that each and every issue philosophers of education address must bear immediately on the work of teachers....It is simply to observe that a philosophical discourse about education that is informed by the practices of schools and other educational institutions is a discourse in the Philosophy of Education" (Feinberg in Kholi 1995, p. 27). Feinberg strengthens his rhetoric further on, "A philosopher who makes mistakes about school practice may still meet the standards of good philosophy. However, a philosopher of education who is consistently uninformed about educational practices and research is failing to meet the standards of the field" (Feinberg, in Kholi, 1995, p. 28). Feinberg pulls no punches here; the philosopher of education that is unaware of the research and the debates regarding educational practice is falling short of his or her professional responsibility and (so it seems) ought not to be credited with the honorific, 'philosopher of education.' Feinberg does not tell us what counts as research in the field of education, or which practices a philosopher of education must inform herself about: presumably, though, these are issues and practices in public schooling.

D.C. Phillips' essay chides the wholesale criticism of Enlightenment rationality. Whereas Greene and others are content to criticize the Enlightenment from the perspectives of postmodernism and Critical Theory, Phillips offers some cautionary advice. "Now Greene and others might respond that this shows how stubborn and blinkered in intellect most Enlightenment-tradition philosophers are; but this response would be one which 'psychologizes' the opponents, and it is one which sidesteps the necessary intellectual task of examining the grounds or warrants that traditional philosophers have for their rejection of postmodernist doubts about epistemology" (Phillips in Kholi 1995, p. 39). Phillips is fearful that our educational system will produce people "who espouse allegiance to critical rationality but who can be swayed by the first argument that comes along that preys on raw emotions or appeals to crass self-interest" (Phillips in Kholi, 1995, p. 41). Phillips does not single out any one particular argument of 
Greene's in reference to this, but it is highly plausible that Greene's criticism of rationality in favor of emotion and feeling is somewhere in the offing. Together, the three essays set the tone for what, in short order, is to come.

\section{The Dilemma of Philosophy of Education}

In the winter of 2002, Educational Theory publishes an essay written by Rene Vincente Arcilla entitled, "Why aren't Philosophers and Educators Speaking to Each Other?" The response to the essay prompts the editor, Nicholas Burbules, to exhort his fellow philosophers of education to contribute to the debate, and the result is the summer 2002 edition, featuring eight well-considered colleague's rejoinder. Arcilla's piece is carefully analyzed and dissected. Several of the contributors point out the hidden premises of such a question: that there is indeed a problem; that the problem constitutes a concern; that philosophers of education need philosophers, etc. It will do to look more closely at these responses to Arcilla's original contribution. I am particularly interested in how these contributors see the role and scope of the philosophy of education and in particular, the relationship of philosophy of education to educational practice.

Arcilla diagnoses the assumed silence between educators and philosophers as brought on by differences of methodology. "What brought on the silence between philosophers and educators was largely the fact that philosophy, with its tradition of skeptical questioning, was less suited to the formation of theoretical attitudes useful for educators than the extra-philosophical, more empirical and positivist social sciences. Educators, therefore, had every reason to bring their social theory needs to the latter, and to make them their chief conversational partner" (Arcilla 2002, p. 10). One solution to this, Arcilla says, is to tie ourselves to social theory and social science. This is (roughly) what Dewey suggested, with the proviso that we 'lose' philosophy. Another is to "discover how to make those parts of philosophy which are precisely not featured in the social sciences pertinent to educators." Arcilla's offerings are in the guise of skeptical questions, such as "What do I know?" and "How do I exist?" (Arcilla 2002, p. 11).

Arcilla's choices are then to follow Dewey, which casts philosophy of education in the role of providing useful social theory to aid in solving educational problems, or help to raise (and presumably, answer) questions that other educators and disciplines are not asking. Arcilla seems to prefer the latter to the former, though with regret he suggests that the former is more likely to happen. In the responses to Arcilla's essay, several different diagnoses and solutions are proffered. I wish to look at several of these contributions in terms of two questions: the first is, is there, or is there not, a problem with discipline of philosophy of education (not necessarily with respect to the relationship with philosophy); the second is, what is to be done about it.

I begin with Eric Bredo. Bredo does seem to think that philosophy of education is in trouble. It "seems to be experiencing growing marginalization today. The glory days when John Dewey was both the foremost American philosopher and education thinker are a distant memory....It seems that philosophy of education is facing a continuing decline amid the ruins of past greatness-not unlike Greece itself” (Bredo 2002, p. 263). Bredo sees the problem in the analytic/continental divide that, he says, results in a frac- 
tured set of common interests. His solution, as with his diagnosis, is different from Arcilla's: Bredo thinks that philosophy of education need limit itself neither to skepticism (philosophy) nor "concede ethics to the social sciences." Instead, it "will have to address its central functions, and perform them well, rather than conceding them to others" (Bredo 2002, p. 263). Bredo claims that philosophy of education must develop "high aspirations for solving philosophy of education's own unique problems. If these are addressed well the field may even alter philosophy and educational practice in small ways rather than taking its marching orders from them" (Bredo 2002, p. 270).

Harvey Siegel disagrees with Arcilla's claim that the field of philosophy of education is in serious peril. If it is in peril, however, it is not because philosophers and philosophers of education are no longer speaking to each other: Siegel himself is proof of the converse. Siegel turns his guns toward Dewey and the Deweyan, progressivist notion that philosophy of education is there to solve educational and social problems: For it is this project that produces the limitations of the discipline. His biggest complaint is if we follow Dewey, we deny the history of philosophy. "The most obvious difficulty with Dewey's picture of philosophy is that, according to it, most major philosophical figures (in the Western tradition, at least) fail to count as "full-fledged" philosophers at all....It seems none of these philosophers' most important work is rightly characterized in terms of formulations of "a general attitude toward [their] social problems..." (Siegel 2002, p. 273). Seigel proudly proclaims that, "Philosophy of Education, like its parent discipline, philosophy, has a dignity and integrity of its own and its survival as a worthy scholarly pursuit is not dependent upon conversation with anyone....If philosophy of education fails to engage educators in conversation, and contributes not a whit to the solution of social problems or the flourishing of democratic society but nevertheless advances its own intellectual agenda...its future is assured" (Siegel 2002, p. 279).

Barbara Stengel does not think that Arcilla's complaints are well founded. Stengel finds that in her capacity as a philosopher of education, she has many instances of contact with educators. In Stengel's opinion, the field "is vital and provocative" (Stengel 2002 , p. 285). She suggests that any separation of philosophers from philosophers of education must take into account the stories of "power, privilege, gender, socioeconomic status, and ideological assumptions, as well as bureaucratic rationalization and reification" (Stengel 2002, p. 286). For Stengel, the prevailing concern is "not the explanatory question of why philosophers and educators aren't speaking to each other. The important question is a moral one about the responsibility of philosophers of education. Why are we not inviting philosophers and educators to join with us and each other in conversation and action in the realm of educational issues" (Stengel 2002, p. 289). Kathleen Knight Abowitz and Audrey Thompson's respective essays also demonstrate this line of thought: the reigning 'conversation' between philosophers and educators is fraught with conflict, power struggles, gender stereotypes, and ideological assumptions. At least some of the work that needs to be done is to unpack these assumptions in the name of more equal relations (Knight Abowitz 2002; Thompson 2002).

Donald Arnstine's essay is unabashedly pro-educational practice. In response to Arcilla's concern of why philosophers and philosophers of education do not speak, Arnstine bluntly says, "Philosophers and educators (including philosophers of educa- 
tion) do not conduct extended conversations with one another because they are employed by different organizations, have different goals, and follow different career paths. What philosophy or education is or ought to be have nothing to do with why practitioners of philosophy or education do not communicate....Inquiries into the nature of philosophy and of education lead us away from, not toward, a solution to Arcilla's problem of alienated self-consciousness" (Arnstine 2002, p. 303-304). Of the loss of prestige and attention regarding the discipline, Arnstine says policymakers, the largest audience historically, have disappeared; these people no longer make school policy. Philosophers of education are without an audience and yet have not responded in any meaningful way to address this state of affairs. Philosophers of education, he says, have shirked their responsibility of addressing the most difficult of policy issues with the result that they have marginalized themselves. "The question, Who decides school goals, and who ought to decide? Is a problem for the public, but it is a problem for philosophers of education as well. It will not be solved by trying to figure out how to get philosophers and educators to talk to each other, but if it is not solved, there will be little use for philosophers of education in this country [the United States]" (Arnstine 2002, p. 307).

Gary Fenstermacher gives an interesting twist to Arcilla's characterization of the problems of dialogue. He suggests (for arguments' sake) that there are two groups of philosophers of education. The first are PE1, those that deal primarily with problems intrinsic to philosophy. The second are PE2, those that deal with problems likely to be of interest to the educator. Fenstermacher suggests that Arcilla identifies more fully with the PE1 philosophers and this is in part, why he has such trouble with the lack of dialogue. Fenstermacher does not share Arcilla's fears.

Arcilla argues that if a philosopher of education engages in social science, he or she goes over to the dark side...ceasing to be seriously engaged in philosophy of education. I contend that a philosopher of education can only be in a substantial and worthwhile dialogical relation with a practicing educator if he or she engages in social science.... The upshot of this line of reasoning is that if you want to have a dialogical relation with a practicing educator, you have to relinquish the doing of serious proper philosophy....If you do serious, proper philosophy, you cannot be in a worthwhile dialogical relation with practicing educators..."

(Fenstermacher 2002, p. 348).

Nicholas Burbules, editor of the journal, has the concluding piece. He maintains that the field is "more intellectually dynamic and robust now than it has ever been." One danger of discussions such as this one is a hearkening back to some kind of Golden Era in which philosophy of education was presumably more important, more rigorous, and more "philosophical" than it is today. I do not believe a survey of the literature would support such a characterization. At any given time, only a small handful of scholars were really doing important, rigorous, and "philosophical" work; most of the rest was derivative and at a fairly mundane level” (Burbules 2002, p. 349). He points out that intellectual vitality of the discipline and institutional viability, to use his words, 
do not 'run on the same tracks,' and that administrators and policy makers have seldom held much of a commitment to philosophers of education. He diagnoses the philosophy of education as composed of a hybrid of often-competing theoretical frameworks, "and, indeed, [it] often relies upon implicit and sometimes explicit arguments that philosophy and theory cannot and should not be kept separate" (Burbules, 2002 p. 352). He appeals in the end to what he calls, "situated philosophy." This philosophy comes closest, in his estimation, to the claims of Barbara Stengel, Kathleen Knight Abowitz, and Audrey Thompson. "It is the work of the philosopher who is involved on site. It associates philosophy not with system building, but with thinking and problem solving...it is particularly suited for philosophers of education.... What this different twist does, of course, is to make the activity of philosophy of education itself an educational relation, for all parties involved. Such involvement is reciprocal, not authoritative, or pedantic" (Burbules 2002, p. 354). It forces the question of 'what gives you the right to criticize' on the inquirer: no longer can she be content to observe, analyze, and dispute from a distance. The requirement seems to be to participate fully in the very topic of discussion undertaken.

\section{Towards a Different Philosophy of Education?}

There are two constants in the North American debates and discussions of what constitutes the philosophy of education: philosophy of education is bound in some manner to educational practice, and philosophy of education is in the service of social reform and improvement. Both of these are legacies of the Deweyan, progressivist past. Both of these go largely unchallenged in the scholarly literature, with a few notable exceptions (Siegel, Bredo, and Arcilla). Moreover, any proffered solution to the concerns raised by those such as Arcilla often lie in tightening the relations between philosophy of education and its parent discipline, education. This is certainly the position of Donald Arnstine and Barbara Stengel. To those that might protest - those that claim this is not the direction the discipline ought to be going - the temptation of philosophy proper might seem attractive. In the same way as Oxford-style Analytic philosophy dominated Great Britain's philosophy of education program for 20 years, unhappy philosophers of education might wish to form a set of disciplinary issues removed from the context of educational practice. They might wish that the discipline would follow with problems that properly belong to the discipline of philosophy, or in any event, problems amenable to the philosophic solutions proffered by a single school of thought. This has recently been brought to the attention of educational scholarship by a number of historians writing on the topic (Kaminsky 1993, Muir 1996; 2004). The tendency is to consider only those problems that arise out of a certain school as legitimate. This of course, ignores the history of the self-understandings of philosophy of education. The question of when philosophy of education began is an unsettled one, and it is dependent on when philosophy of education became self-aware and self-legitimating. Those such as Kaminsky think that the discipline began in the 1930's with the founding of organizations dedicated to the pursuit of scholarship. Those such as Muir see a vast philosophy of education enterprise stretching back some 2,500 years, tied together with contemporary philosophy of education in part by the mutual questions asked. 
I argue that neither yoking philosophy of education to extant educational practices nor to a philosophical school of thought that artificially limits what counts as educational philosophy will solve the problem. In fact, these may worsen the situation. For not only do the issues and concerns, for example, of philosophy not have a direct link to any questions that philosophy of education might develop, these also have little to do with education, properly speaking. To travel from educational practice to philosophy if this means taking up the questions common to a school of philosophy wholesale, is tantamount to trading one set of foreign issues and concerns for another.

Not surprisingly, I believe that we ought to give up the attempt at hitching our wagons to philosophic stars. However, we should not reject out of hand the vast resources available to us from philosophy as well as other disciplines. The answer to the quandary lies in the sorts of questions that we ask ourselves. It is not that the resources other disciplines provide are non-genuine: our attempts at using these to inform questions that do not properly belong to us are. Only genuine questions, drawn from the well of philosophy of education, not philosophy or educational practice, will have the wherewithal required to make the resources we use beneficial. In this, I am in agreement with Eric Bredo.

This leads me to ask that perennial question: what questions does philosophy of education ask? What questions, that is, are unique to philosophy of education? Are these, in fact, the questions that we do ask when we do philosophy of education? If not, then what is at stake in re-examining these anew? To the last question, I answer: a great deal: it challenges received questions asked in philosophy of education (much the same way these questions challenged older ones). Yet, I would argue, this is precisely what Dewey of all people has in mind when he writes regarding the disciplines of psychology and sociology in relation to education; that education must develop not only its own research and resources, but also its own problems and questions. Commenting on the role of these in education, Dewey says,

This matter opens up the field of educational values and objectives. How are they to be determined? From what are they derived? The assumption that gives rise to the procedures just criticized is the belief that social conditions determine educational objectives. This is a fallacy. Education is autonomous and should be free to determine its own ends, its own objectives. To go outside the educational function and to borrow objectives from an external source is to surrender the educational cause. Until educators get the independence and courage to insist that educational aims are to be formed as well as executed within the educative process, they will not come to consciousness of their own function. Others will then have no great respect for educators because educators do not respect their own social place and work (Dewey 1984, p. 38).

This project seems to imply the reconstruction of existing philosophy of education. This is correct. Education is to develop its own questions, then philosophy of education, as a subfield of philosophy and education, yet a discipline in its own right, ought to develop its own subset of questions. We begin, in other words, where Dewey leaves off. 
To suggest that we take our point of departure from Dewey is to suggest that Dewey's is the most influential and lasting achievement in North American educational philosophy. Few would disagree that anything remotely as vast and ambitious has come forth since then. Dewey's is a still-dominant voice in educational philosophy and theory, at least in North America. Moreover, many of those skeptical of philosophy and current educational practices agree that Dewey's vision for education remains a powerful, if impractical, one. The tendency in the past 30 years has been to question systematic enterprises; to analyze instead of synthesize, to deconstruct instead of build. I suggest the time has come for philosophy of education to answer, to synthesize, and to re-build. I see no better way to do so than to begin by looking at the history of our selfunderstandings of philosophy of education and do so with an eye on what constitutes legitimate questions. I think if we do this, we will be able to free ourselves from the parochialism common to much recent scholarship.

What might this mean in disciplinary terms? I will discuss this with reference to some examples I find inhibitive of a reconstructed philosophy of education. First, we must cease to be ahistorical. By this, I mean having little or no role for our past selfunderstandings to play in present or future theory. As well, there is a strong tendency towards anachronism; that is, making the present context, with its associated problems, determine the worthiness of past theories and ideals. This is both unfortunate and misleading. Past theories and ideals are not in a position to be judged by present lights until they are conscientiously re-appropriated for the contexts they are to serve in. I am not saying that these prior ideals are problem-free or cannot be criticized: I am saying that much criticism proceeds as if these ideals arose in a vacuum. This is not acceptable: we must interpret our novel philosophies of education in light of the past.

Second, we must reconstruct what is good and right about these philosophies and theories, and jettison what is not. The criteria for 'good and right' are debatable; but at the very least, they should include the relevance to genuine questions philosophy of education (not philosophy, educational practice, or other disciplines). We should not re-invent the wheel through re-introduction of dubious theories and ideals. Equally, though, we should not forgo those ideas and ideals that are, and have been, beneficial. We must make sure, however, that these latter are placed squarely in the context of the present. What constitutes a legitimate placement is the sensitivity to the needs of the problems we currently form and have. There is benefit to a 'hermeneutics of suspicion,' but only insofar as this helps us to contextualize ideas and ideals in the face of our legitimate problems. This is the frequently made call for 'immanent' critique of existing (or past) philosophical traditions in education.

Third, when we focus on interdisciplinary issues or ideals of other disciplines (including philosophy and education) we should keep in mind the need to set these in our historical and philosophical context. Ideas from outside the purview of philosophy of education require contextualization in their appropriation to philosophy of education. Part of the problem of course, is that we cannot decide on what philosophy of education's terrain is. We jeopardize our claims to be a bona-fide discipline when we cannot agree what counts as philosophy of education. My (earlier) suggestion is that we begin with legitimate problems proper to philosophy of education and by doing so we 
'carve out' a terrain of our own. We can reconstruct ideas and ideals outside of the philosophy of education through their appropriation, but we must be sensitive to what it means for our discipline. We should reconstruct these in light of our genuine problems and the 'solutions' to these, rather than to pseudo-problems properly belonging to other disciplines. How does this change our existing ideas and ideals? Is this change a legitimate one in light of the present problems we face? What does this mean for our existing 'metanarratives?' - our unquestioned assumptions of what philosophy of education is/does? Are there normative implications for these theoretical/philosophical changes? What are they, and why should we attend to them? Are there good reasons to be skeptical of such ideas and ideals, given their relationship to legitimate problems?

Fourth, purportedly context-free value judgments and normative claims should be avoided, or at the very least, set in the context of philosophy of education's goals (not the goals of other disciplines, whether educational practice, politics, cultural studies, or sociology). While it may be the case that a particular idea or ideal helps to us to theorize political problems, for example, it is beyond the wherewithal of philosophy of education to simply legitimate this theorization. This is not because philosophy of education is 'pure,' or 'above' educational practice; it is because philosophy of education does not have the tools, ideas, or ideals to make the sorts of arguments (and conclusions) that educational practice (for example) does, and in any event, the goals of educational practice are different from those in philosophy of education. While it may be acceptable for educational practice to draw from philosophy of education, the pronouncement of philosophy of education on a practical matter is inappropriate. Philosophy of education does not have suitable goals, to say nothing of the disciplinary apparatus (theories, ideals, research) to make such pronouncements.

These recommendations will no doubt strike many readers as ill-considered or even anathema. Those with stakes in educational practice, as well as other disciplines, will likely take umbrage at these suggestions. Let me clear once more; my aim is not to close these fields off to philosophy of education. My aim is to carve out a terrain for philosophy of education and to do this requires settling on our own problems, not the problems of other areas and disciplines. The debates within educational practice, politics, and sociology, for example, are of interest to philosophers of education. However, these only take on philosophical importance if we re-contextualize them in light of the existing problems of philosophy of education. A practical problem in a practical context is not prima facie a problem for philosophy of education. Though we may have our personal, and even institutional, views on these matters, these are not admissible as disciplinary pursuits. Until we begin to re-contextualize the problems in other disciplines that we assume, we will not be able to carve out the terrain we wish.

\section{Endnotes}

1 This is not the case with poststructuralism, deconstructionism, postmodernism, cultural studies and other current theory. This is likely due to the skepticism that pervades these: skepticism about the possibility of their being any non-question-begging authoritative stance, including non-metaphysical and non-public stances, prevents the possibility of collaborating with pragmatism (Shusterman 1997, p. 27). The aestheticization of theory; 
the view that the private, inner self is what is to be championed, is above all inimical to the strongly social cultivation of pragmatism. No doubt these models allow and even embrace, so-called 'standpoint epistemology' - the epistemology of the socially constructed knower but this does not mesh with Deweyan pragmatism. There does not seem to be a place for a Deweyan theory of experience in these models. Nor does there seem to be much left for philosophy of education: inasmuch as these thinkers eschew grounding educational practices and claims in logic, metaphysics, or epistemology, it seems philosophy of education could have nothing to contribute to their thinking, and it is (to my mind anyways) doubtful whether these have anything to contribute to philosophy of education.

2 In the case of Great Britain, a diametrically opposite situation is notable: the near-absence of schools, schooling, or social problems in the discourse during the period in question. This is however, no longer the case. Recent submissions to the journal indicate that social reform issues vie for control of space (See Kaminsky 1993). I shall have more to say about this further on.

3 The most famous of the perrenialists to criticize Dewey's progressivist notions of education is of course, Robert Hutchins. Dewey and Hutchins responded to each other in a series of articles in the early and mid-1940's. Essentialists critical of Dewey included Arthur Bestor and Richard Hofstadter. Anti-liberals critical of Dewey include the Illinois Revisionist School, as well as notable cultural critics such as Christopher Lasch. Interestingly, John Dewey has appeared on David Horowitz's top 100 most dangerous books in America, topping in at number four!

4 The disciplinary self-consciousness that philosophers of education have is a partial explanation as to why Kaminsky does not include figures of such eminent stature as Plato and Rousseau. The self-understandings of the discipline do not properly begin, Kaminsky intimates, until such time as Dewey and Deweyan progressivist educational theory instantiate themselves in colleges of education. Until then, philosophy of education is not, to borrow Hegel's terms, 'in and for itself.' This view has been vociferously challenged, notably by John Muir (1996; 2004).

5 It is curious that she quotes from Oakeshott. Even though the passage in question agrees in the main with her premise, nevertheless, Oakeshott would have vociferously defended the claim that tradition has its own compelling justification, and that political change for the sake of present need is unacceptable in the face of this (Oakeshott, 1991, p. 63).

\section{References}

Arcilla, R. V. (2002). Why Aren't Philosophers and Educators Speaking to Each Other? Educational Theory 52(1), 1-11.

Boler, M. (2000). An Epoch of Difference: Hearing Voices in the Nineties. Educational Theory 50(3), 357-382.

Burbules, N. (2002). The Dilemma of Philosophy of Education: Relevance or Critique? Part Two. Educational Theory 52(2), 349-358.

Champlin, N. Committee of the Philosophy of Education Society. (1970). The Distinctive Nature of the Discipline of the Philosophy of Education. In C. J. Lucas (Eds.), What is Philosophy of Education? (pp. 111-113). London: The MacMillan Co.

Cremin, L. (1962). The Transformation of the School: Progressivism in American Education 1876-1957. New York: Vintage.

Cremin, L. (1988). American Education: The Metropolitan Experience 1876-1980. New York: Harper and Row.

Dewey, J. (1980). Democracy and Education. In J. Boydston (Ed.). The Middle Works of John Dewey Vol. 9, 1916. Carbondale, IL: Southern Illinois University Press.

Dewey, J. (1984). The Sources of a Science of Education. In J. Boydston (Ed.). The Later Works of John Dewey Vol. 5, 1929-1930. (1-40). Carbondale, IL: Southern Illinois University Press. 
Dewey, J. (1984). "Education and the Social Order." In J. Boydston (Ed.). The Later Works of John Dewey Vol. 9, 1933-1934. (175-186). Carbondale, IL: Southern Illinois University Press.

Feinberg, W. The Discourse of Philosophy of Education. In W. Kholi (Ed.). Critical Conversations in Philosophy of Education (pp. 24-33). New York: Routledge.

Feinberg, W. and Odeshoo, J. (2000). Educational Theory in the Fifties: The Beginning of a Conversation. Educational Theory, 50(3), 289-306.

Fenstermacher, G. (2002). Should Philosophers and Educators be Speaking to Each Other? Educational Theory 52(2), 339-348.

Greene, M. (1995). What Counts as Philosophy of Education? In W. Kholi (Ed.). Critical Conversations in Philosophy of Education (pp. 3-23). New York: Routledge. Greene, M. (2000).

Greene, M. (2000).The Sixties: The Calm Against the Storm, Or, Levels of Concern. Educational Theory 50(3), 307-320.

Kaminsky, J. (1993). A New History of Educational Philosophy. Westport CT: Greenwood Press, 1993.

Kliebard, H. (1995). The Struggle for the American Curriculum. New York: Routledge. Kholi, W. (2000). Educational Theory in the Eighties: Diversity and Divergence. Educational Theory 2000, 50(3), 339-356. Labaree, D.F. (2004). The Trouble with Schools. New Haven: Yale University Press.

Lagemann, E.C. (1989). “The Plural Worlds of Educational Research.” History of Education Quarterly, 29(2), 184-214.

Muir, J. (1996). The Evolution of Philosophy of Education within Educational Studies. Educational Philosophy and Theory, 28(2), 1-26.

Muir, J. Is there a History of Educational Philosophy? John White vs. the Historical Evidence. Educational Philosophy and Theory,36(1), 35-56.

National Society for the Study of Education. (1942). Philosophies of Education: The Forty-first Yearbook of the National Society for the Study of Education. Part 1. N. B. Henry (Ed.). Chicago: University of Chicago Press.

National Society for the Study of Education. (1955). Modern Philosophies and Education: The Fifty-fourth Yearbook of the National Society for the Study of Education. Part 1.

N. B. Henry (Ed.). Chicago: University of Chicago Press.

National Society for the Study of Education.(1981). Philosophy and Education: Eightieth Yearbook of the National Society for the Study of Education, Vol. 1. J.F. Soltis (Ed.). Chicago: University of Chicago Press.

Oakeshott, M. (1991). Political Education. In Rationalism and Politics and Other Essays (pp. 43-69). Indianapolis: Liberty Fund.

Phillips, D.C. (1995). Counting Down to the Millennium. In W. Kholi (Ed.). Critical Conversations in Philosophy of Education (pp. 34-44). New York: Routledge.

Phillips, D. C. (2000). Interpreting the Seventies, Or, Rashomon Meets Educational Theory. Educational Theory, 50(3), 321-338.

Shusterman, R. (1997). Practicing Philosophy: Pragmatism and the Philosophical Life. New York: Routledge.

Siegel, H. (1981). The Future and Purpose of Philosophy of Education. Educational Theory $31(1)$.

Stengel, B. (2002). Cause for Worry or Agenda for Action? Educational Theory, 52(3), 281-290.

Tanner, D. (1991). Crusade for Democracy: Progressive Education at the Crossroads. Albany: SUNY Press.

Tyack, D. (1974). The One Best System. Cambridge: Harvard University Press.

Welker, R. (1992). The Teacher as Expert. Albany: SUNY Press.

White, J. (1999). Philosophers on Education. Journal of Philosophy of Education,33(3), 41-52. 